Volodymyr Velychko, Evgen Grytskov, Dmitriy Zubarev

\author{
O. M. Beketov National University of Urban Economy in Kharkiv, Ukraine
}

\title{
DIRECTIONS FOR THE DEVELOPMENT OF A STAKEHOLDER-ORIENTED STRATEGY FOR MANAGING CONSTRUCTION ENTERPRISES: DOMESTIC AND INTERNATIONAL EXPERIENCE
}

It is proved that in modern conditions, the formation of directions for the development of a stakeholder-oriented strategy for managing construction enterprises, taking into account domestic and international experience and the impact of social corporate responsibility, is gaining importance. The aim of the study is to identify areas for the development of a stakeholder-oriented strategy for managing construction enterprises, taking into account domestic and international experience and especially the formation and implementation of social corporate responsibility. To achieve this goal, the study solves the following tasks: analysis of existing domestic provisions on the formation and ensuring interaction between stakeholders of construction companies; identification of the main aspects of stakeholder relations in international practice; formation of directions for the development of a stakeholder-oriented strategy for managing construction enterprises, taking into account the impact of social corporate responsibility. As a result of the study, directions for the development and implementation of a stakeholder-oriented management strategy for construction enterprises were proposed, which made it possible to identify methods and models, formulate a methodological approach for integrated assessment of the level of stakeholder relations, and develop measures to increase the effectiveness of stakeholder interaction aimed at increasing the investment attractiveness of construction enterprises. It is proposed to apply the developed strategy in domestic and international practices (Chinese construction enterprises), taking into account social corporate responsibility while ensuring interaction with various groups of stakeholders.

Keywords: stakeholder-oriented strategy, management, construction enterprises, the functioning of the Chinese construction market, stakeholders, social corporate responsibility.

\section{Introduction}

In the conditions of permanent transformations taking place in the internal and external environment, the turbulence of the national economy, the rethinking of approaches to ensuring the management of enterprises is of particular importance. At the same time, the focus of attention is focused on taking into account and increasing the effectiveness of interaction between stakeholders, taking into account international experience. Construction enterprises are important for the functioning and development of the state economy; they affect other areas. In recent years, there have been mixed trends in the construction sector, where there are no clear directions for the development and strengthening of production and economic potential.

It should be noted that in modern conditions the use of innovative methods and models to ensure interaction with stakeholders, which can be used in international practices, is of particular importance. In particular, one of the most developed economies in the world - Chinese - in 2019. Demonstrates trends characterized by the accumulation of negative phenomena. In the third quarter of 2019 , China's GDP growth was only $6 \%$, which is the worst indicator since 1992 [1]. This situation is due to external influences (trade wars with the United States) and internal imbalances, it needs to stimulate reform and innovation.

Thus, taking into account the above, the topic of the study on the development of a stakeholder-oriented strategy for managing construction enterprises is relevant and important in the domestic and international aspects.

\section{Analysis of existing research}

Scientists were engaged in solving the problems of the formation and implementation of the management strategy of construction enterprises, taking into account the directions and features of interaction with stakeholders [2 - 15]. Along with this, there are no unified approaches to the development of a stakeholder-oriented strategy for managing construction enterprises.

\section{The objectives of the study}

The aim of the study is to identify areas of development of a stakeholder-oriented strategy for managing construction enterprises, taking into account domestic and international experience, especially the formation and implementation of social corporate responsibility.

To achieve this goal, the study solves the following tasks:

(C) Величко В.А., Грицьков Є.В., Зубарєв Д.В. 
- analysis of existing domestic regulations on the formation and ensuring interaction between stakeholders of construction enterprises;

- determination of the main aspects of stakeholder relations in international practice;

- formation of directions for the development of a stakeholder-oriented strategy for managing construction enterprises, taking into account the impact of social corporate responsibility.

\section{Main part}

To ensure the effectiveness of interaction between stakeholders and the adoption of informed management decisions for the development of construction enterprises, a stakeholder-oriented strategy for their management is proposed. In the dissertation, the directions of its development and implementation, which are characterized by:

the formation and application of information and analytical support for the interaction of stakeholders of construction enterprises;

regulatory support for the functioning and development of construction enterprises, determination of areas and characteristics of interaction between interested parties;

tools for the formation and determination of factors affecting stakeholder relationships;

the construction of a multi-level system of indicators for the formation and implementation of stakeholder relations;

the formation and use of methods and models for determining systemic factors in the system of stakeholder relations of construction enterprises;

assessment of systemic factors affecting the formation and implementation of stakeholder relationships;

determination of weight coefficients characterizing the influence of system factors on the integral indicator of the level of stakeholder relations of construction enterprises;

the construction of an integral model for determining the generalized indicator of the level of stakeholder relations;

determination of an integral indicator of the level of stakeholder relations of construction enterprises;

based on the developed quantitative basis, the proposed growth directions of the integral indicator of the level of stakeholder relations;

the development of a methodological approach to the integrated assessment of the level of stakeholder relations of construction enterprises;

development of a model for assessing the investment attractiveness of construction enterprises;

assessment of the integral indicator of their investment attractiveness;

the construction of an economic-mathematical model of the influence of an integrated indicator of the level of stakeholder relations on the generalizing factor of investment attractiveness of construction enterprises;

determination of the criteria for the adequacy of the economic-mathematical model of the influence of the integral indicator of the level of stakeholder relations on the generalizing factor of investment attractiveness;

the use of neural technologies to confirm the criteria for the adequacy of the economic-mathematical model and determine the forecast values of the integral indicator of the level of stakeholder relations in the context of its influence on the generalizing factor of investment attractiveness of construction enterprises;

by development Enter the growth of investment attractiveness of construction enterprises depending on changes in the level and effectiveness of interaction between stakeholders;

constructing a scheme for the formation of a stakeholder strategy for managing construction enterprises;

development of an algorithm for implementing a stakeholder management strategy for construction enterprises.

Describing the directions presented, it should be noted that the formation and use of information and analytical support for the interaction of stakeholders of construction enterprises is carried out on the basis of statistical, financial and other reports on the activities of construction enterprises, primary documents, contractual obligations regarding the borrowing of interested parties. Of particular importance is the use of information from the State Statistics Service of Ukraine regarding the functioning of the construction sector. The information and analytical support is presented that forms a systematic quantitative basis for the development and implementation of a stakeholder-oriented management strategy for construction enterprises, taking into account internal and external conditions.

The formation of regulatory support for the functioning and development of construction enterprises, the determination of areas and characteristics of interaction between interested parties is carried out on the basis of the existing legislative framework for the development of the construction sector.

Regulatory support includes other legislative acts that affect the functioning and development of the construction industry. However, in the existing legislative field, the legislative framework governing relations between stakeholders, moreover in the construction sector, is not clearly distinguished.

In international practices, special attention is paid to the directions and features of interaction with stakeholders. In particular, in the Guidelines for consultation with stakeholders developed by the European Commission: general principles and standards are defined. The principles of interaction between the interested parties are: comprehensiveness; openness and accountability; efficiency; consistency [16]. 
Highlighted standards of interaction aimed at ensuring clarity, determination, publicity, ensuring and confirming feedback. It was proposed to create roadmaps for interaction with stakeholders [16].

For structuring stakeholders, the following areas have been formed: determination of target groups; search for balance and comprehensive coverage; the influence of other stakeholders; the use of clear and transparent criteria that ensure interaction with stakeholders [16].

In this context, the development of legal support for a clear identification of areas of interaction with stakeholders at construction enterprises is of particular importance.

The study proposed a toolkit regarding the formation and determination of factors affecting stakeholder relationships: the method of expert assessments - for selecting factors; generalization of theoretical and methodological approaches to determining stakeholders and identifying the features of their interaction at construction enterprises; systematization of regulatory support for the functioning and development of construction enterprises, taking into account the directions and features of interaction with interested parties; methods for assessing strategic positions - for the selection and determination of factors affecting the formation and implementation of strategic directions of activity of construction enterprises, taking into account the peculiarities of interaction with stakeholders. The presented direction of the development and use of a stakeholder-oriented management strategy for construction enterprises was implemented in the previous sections of the dissertation.

A multi-level system of indicators for the formation and implementation of stakeholder relations is built, which includes the following levels:

Level 1: an integral indicator of the formation and implementation of stakeholder relations of construction enterprises $\left(I_{S}\right)$.

Level 2: systemic factor of quality and level of fulfillment of contractual obligations $\left(S_{1}\right)$; systemic factor of the level of interaction of the studied construction enterprises with various groups of stakeholders $\left(S_{2}\right)$; a systemic factor in the formation and implementation of corporate governance of construction enterprises to ensure interaction with stakeholders $\left(S_{3}\right)$; systemic factor ensuring the interaction of stakeholders in the context of the formation and implementation of strategic directions for the functioning of construction enterprises $\left(S_{4}\right)$; systemic factor that determines the socio-economic and innovative level of construction enterprises, which are provided through the interaction of stakeholders $\left(S_{5}\right)$; systemic factor of the strategic state of construction enterprises $\left(S_{6}\right)$.

Level 3: local factors of the level of stakeholder relations.

It should be noted that for the formation of a quantitative basis for the development and implementation of a stakeholder-oriented management strategy for construc- tion enterprises for indicators of the 3rd level of the formation of system factors that ensure the interaction of stakeholders in the context of the formation and implementation of strategic directions for the functioning of construction enterprises $\left(S_{4}\right)$ and the factor that determines social-economic and innovative level of construction enterprises, which are provided through the interaction of stakeholders $\left(S_{5}\right)$, a restriction is introduced: the most influential indicators are used.

The next step in the development and implementation of a stakeholder-oriented management strategy for construction enterprises is the formation and use of methods and models for determining systemic factors in the system of stakeholder relations of construction enterprises. In this case, the geometric mean estimation model is applied using the analytical method (Table 1).

Based on the proposed models, an assessment is made of systemic factors affecting the formation and implementation of stakeholder relations.

The determination of weight coefficients characterizing the influence of system factors on the integral indicator of the level of stakeholder relations of construction enterprises is implemented by applying the method of analysis of hierarchies.

The construction of an integrated model for determining the generalized indicator of the level of stakeholder relations, which has the form:

$$
\begin{aligned}
& I_{s}=k_{s 1} x S_{1}+k_{s 2} \times S_{2}+k_{s 3} x S_{3}+ \\
& k_{s 4} x S_{4}+k_{s 5} \times S_{5}+k_{s 6} \times S_{6} \\
& I_{s} \text { - integral indicator of the level of stakeholder rela- } \\
& \text { tions, rel. units }
\end{aligned}
$$

$k_{s 1}, k_{s 2}, k_{s 3}, k_{s 4}, k_{s 5}, k_{s 6}$ - weighting factors determining the influence of system factors on the integral indicator of the level of stakeholder relations, rel. units

Based on the proposed model, an integral indicator of the level of stakeholder relations of construction enterprises is evaluated. This will create a quantitative basis for the development of measures to improve the efficiency of stakeholder relations of construction enterprises.

The preliminary stages of the development and implementation of a stakeholder-oriented strategy are presented. They are summarized in a methodological approach to an integrated assessment of the level of stakeholder relations of construction enterprises.

Within the framework of a stakeholder-oriented management strategy for construction enterprises, the model is sampled and, based on it, an integral indicator of their investment attractiveness is assessed as a general indicator characterizing the development opportunities of enterprises and the level of ensuring their effective functioning.

The directions of the implementation of the processes of economic and mathematical modeling of the influence of the integral factor of the level of stakeholder relations on the integral indicator of investment attractiveness are determined. 
Table 1

Models for assessing systemic factors in the system of stakeholder relations of construction enterprises (developed by the author)

\begin{tabular}{|c|c|}
\hline The name of the system factor & Model \\
\hline $\begin{array}{l}\text { Systemic factor of quality and level of fulfillment of contractual } \\
\text { obligations }\left(S_{I}\right)\end{array}$ & $S_{1}=\sqrt{S_{11} x S_{12}}$ \\
\hline $\begin{array}{l}\text { The systemic factor of the level of interaction of the studied con- } \\
\text { struction enterprises with various groups of stakeholders }\left(S_{2}\right)\end{array}$ & $S_{2}=\sqrt[14]{\begin{array}{c}S_{21} x S_{22} x S_{23} x S_{24} x S_{25} x S_{26} x S_{27} x S_{28} x S_{29} x S_{210} x S_{211} \\
x S_{212} x S_{213} x S_{214}\end{array}}$ \\
\hline $\begin{array}{l}\text { The systemic factor in the formation and implementation of corpo- } \\
\text { rate governance of construction enterprises to ensure interaction } \\
\text { with stakeholders }\left(S_{3}\right)\end{array}$ & $S_{3}=\sqrt[8]{S_{31} x S_{32} x S_{33} x S_{34} x S_{35} x S_{36} x S_{37} x S_{38}}$ \\
\hline $\begin{array}{l}\text { Systemic factor ensuring the interaction of stakeholders in the con- } \\
\text { text of the formation and implementation of strategic directions for } \\
\text { the functioning of construction enterprises }\left(S_{4}\right)\end{array}$ & 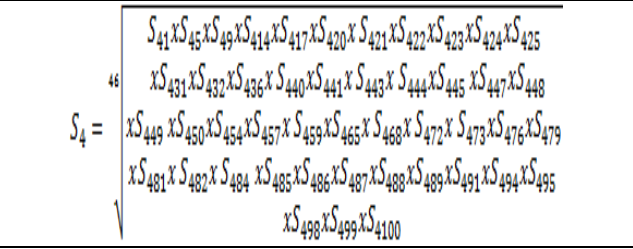 \\
\hline $\begin{array}{c}\text { The systemic factor that determines the socio-economic and inno- } \\
\text { vative level of construction enterprises, which are provided } \\
\text { through the interaction of stakeholders }\left(S_{5}\right)\end{array}$ & 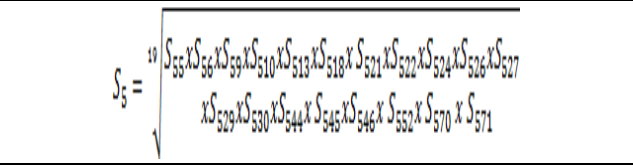 \\
\hline $\begin{array}{l}\text { Systemic factor of the strategic state of construction enterprises } \\
\qquad\left(S_{6}\right)\end{array}$ & 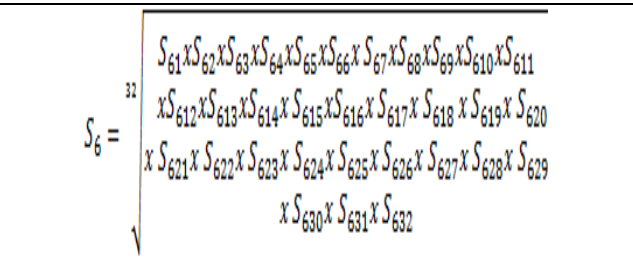 \\
\hline
\end{tabular}

The proposed criteria for the adequacy of the economic and mathematical model: correlation and determination coefficients, Student t-test, Fisher F-test, criteria for checking for homo or heteroskedasticity, Darbin Watson, tests for multicolinearnism. The use of modern tools of neural networks confirms the reliability of economic and mathematical modeling and allows forecasting changes in the investment attractiveness of construction enterprises depending on the transformations taking place in the system of stakeholder reltions. The processes of economic and mathematical modeling create opportunities to form a quantitative basis and increase the effectiveness of interaction between stakeholders to form directions for the development of construction enterprises based on the growth of their investment attractiveness.

Based on the established relationships, certain areas of increasing the integral indicator of the level of stakeholder relations of construction enterprises, measures are being developed to increase the investment attractiveness of construction enterprises.

The resulting direction of the study is to build a scheme for the formation of a stakeholder-oriented strategy for managing construction enterprises and developing an algorithm for its implementation.

For the implementation of the proposed strategy, the directions and features of the formation and implementation of social corporate responsibility at the level of interaction of stakeholders are of particular importance. The study found an insignificant level of formation and implementation of organizational management in the system of social corporate responsibility; insignificant level of ensuring human rights; insignificant level of formation and features of labor practices; insignificant level of environmental protection; an insignificant level of formation and implementation of good practices in the corporate responsibility system has been established; solving problems related to consumers; construction enterprises at an insignificant level participate in the life of communities and their development; insignificant level of definition of corporate social responsibility; an insignificant level of stakeholder discovery and interaction with them in the system of social corporate responsibility; insignificant level of attitude of the organization to social corporate responsibility; insignificant level of formation of social responsibility of the organization; insignificant level of implementation of practical aspects for the end-to-end integration of social corporate responsibility; insignificant level of information exchange on corporate social responsibility; an insignificant level of ensuring increased confidence of the enterprise in social corporate responsibility; insignificant level of analysis and modernization of the activities and practical activities of the enterprise related to corporate social responsibility; an insignificant level of development and implementation of a system of social corporate responsibility to ensure interaction with stakeholders; insignificant level of formation and imple- 
mentation of corporate governance in the system of social responsibility; an insignificant level of ensuring labor relations in the system of social corporate responsibility; an insignificant level of interaction on the formation of marketing relations in accordance with social corporate responsibility; an insignificant level of protecting the health and safety of consumers; insignificant level of sustainable consumption in the system of social corporate responsibility; insignificant level of information protection and consumer confidentiality; slowed pace of development and interaction with the community in the system of social corporate responsibility; insignificant level of employment in the system of social corporate responsibility; insignificant level of introduction of modern technologies in the system of social corporate responsibility; an insignificant level of wealth and income formation in the system of social corporate responsibility; insignificant level of formation of a healthy lifestyle in the system of social corporate responsibility; insignificant level of social investment in the system of social corporate responsibility; an insignificant level of determining the features of the formation of social corporate responsibility of the enterprise; insignificant level of trust in the enterprise in the system of social corporate responsibility.

It should be noted that to ensure the development, in particular, of Chinese construction companies, the use of a stakeholder-oriented strategy for their management, taking into account social corporate responsibility, is important. In recent years, there has been an increase in the share of Chinese construction companies in the global construction market, a sign of internal processes is an increase in the value and proportion of private capital. Implementation of a stakeholder-oriented management strategy at Chinese construction enterprises is carried out in accordance with the existing classification forms of stakeholders:

- in accordance with the organizational form of the enterprise's assets and legal liability, private, partnershipbased enterprises, corporate enterprises;

- in accordance with economic forms: state, collective, family, joint, joint-stock, foreign enterprises;

- respectively, in the area of production: a comprehensive, specialized and service-oriented enterprise;

- in accordance with the model of enterprises: large, medium and small construction enterprises;

- in accordance with the terms of the investment: general contractor, specialized subcontracting and recruiting company [17].

\section{Conclusions}

Thus, as a result of the study, directions for the development and implementation of a stakeholder-oriented management strategy for construction enterprises were proposed, which made it possible to identify methods and models, formulate a methodological approach for integrated assessment of the level of stakeholder relations, and develop measures to increase the effectiveness of stakeholder interaction aimed at increasing the investment attractiveness of building enterprises. It is proposed to apply the developed strategy in domestic and international practices (Chinese construction enterprises), taking into account social corporate responsibility while ensuring interaction with various groups of stakeholders.

\section{References}

1. The growth rate of the Chinese economy fell to the minimum in almost 30 years (n.d.).

2. Grytskov, E. (2018) A stakeholder-oriented approach to managing construction companies. Business navigator, 3-1(46).

3. Grytskov, E. (2016) Organizational and economic support of intellectual capital management at construction enterprises. Abstract for the degree of Candidate of Economic Sciences in the specialty: 08.00.04, 21.

4. Gerasimchuk, V.G. (2000) Strategic Management Enterprise. Graphic Modeling, 360.

5. Ivanov, Y.B (2006) Theoretical foundations of competitive enterprise strategy: Monograph, 383.

6. Mamonov, K.A, Prunenko, D.O., Ugodnikova O.I (2017) Formation of a system of information and analytical support for the strategy of management of intellectual capital of construction enterprises. Bulletin of the economy of transport and industry- messengers, 153-163.

7. Mamonov, K.A 2012) Stakeholder model of integrated brand capital management of construction corporate enterprises.

8. Ponomarenko, V.S., Pushkar, O.I, Tridid, O.M. (2002) Strategic Management of Enterprise Development, 640.

9. Prunenko, D.O (2019) Theoretical and methodological aspects of the formation and implementation of the strategy of management of intellectual capital of construction enterprises. Dissertation for the Doctor of Economic Sciences specialty: 08.00.04, 604.

10. Steiner, G., and Mayer, J. (1998) Strategic Management: Principles and International Practice, 352.

11. Tridid, O.M (2002) Organizational and economic mechanism of strategic development of the enterprise, 364.

12. Shershnev, Z.E. (2004) Strategic Management, 699.

13. Glueck, W.F., Jauch, L.R. (1988) Business Policy and Strategic Management, 940.

14. Henderson, B. (1989) The origin of strategy, 139-143.

15. Robert, S. Kaplan, David, P. Norton (2004) Strategy Maps: Converting Intangible Assets into Tangible Outcomes, 324.

16. Guidelines for Better Regulation, European Commission, Strasbourg (2015).

17. Analysis of features of the Chinese construction industry, investment projects of Chinese construction enterprises, their methods and mechanisms.

\section{Література}

1. Темпы роста экономики Китая упали до минимума почти за 30 лет. [Електронний ресурс]. - Режим доступу https://www.rbc.ru/economics/18/10/2019/5da998fd9a7947940 c5a7562.

2. Грицьков, С. В. Стейкхолдерно-орієнтований підхід до управління будівельними підприємствами. [Електронний ресурс] / С.В. Грицьков // Науково-виробничий журнал "Бізнес-навігатор». Випуск 3-1 (46) 2018. Режим доступу http://business-navigator.ks.ua/journals/2018/46_1_2018/26.pdf.

3. Грицьков, Є. В. Організаційно-економічне забезпечення управління інтелектуальним капіталом на будівельних підприємствах. [Текст] / С.В. Грищьков; Автореферат на здобуття наукового ступеня кандидата економічних наук зі спеціальності 08.00.04 - економіка та управління 
підприємствами (за видами економічної діяльності). - Х.: ХНУМГ імені О. М. Бекетова, 2016. - 21 с.

4. Герасимчук, В.Г. Стратегічне управління підприємство. Графічне моделювання [Текст]: навч. посібник / В.Г. Герасимчук. - К.: КНЕУ, 2000. -360 c.

5. Іванов, Ю.Б. Теоретичні основи конкурентної стратегї підприємства [Текст]: Монографія / Ю.Б. Іванов та ін.; За заг. ред. Ю.Б. Іванова; ХНЕУ. - Х.: ВД “ІНЖЕК”, 2006-383с.

6. Мамонов, К. А. Формування системи інформаційноаналітичного забезпечення стратегії управління інтелектуальним капіталом будівельних підприсмств [Текст] / К. А. Мамонов, Д. О. Пруненко, О. І. Угоднікова // Вісник економіки транспорту і промисловості. - 2017. - № 60. - С. 153-163.

7. Мамонов, К. А. Стейкхолдерна модель інтегрованого управління капіталом бренду будівельних корпоративних підприємств. [Електронний ресурс] / К.А. Мамонов // Комунальне господарство міст. Науково-технічний збірник №106. - Режим docmyny http://eprints.kname.edu.ua/29416/1/ 389396\%20Мамонов\%20KA.pdf.

8. Пономаренко, В.С. Стратегічне управління розвитком підприємства [Текст]: навч. посібник / В.С. Пономаренко, О.І. Пушкар, О.М. Тридід. - Х.: Вид-во ХДЕУ, 2002. - 640 с.

9. Пруненко, Д. О. Теоретико-методологічні аспекти формування та реалізаиії стратегії управління інтелектуальним капіталом будівельних підприсмств. [Текст] / Д.О. Пруненко; Дисертачія на здобуття доктора економічних наук зі спечіальності 08.00.04 - економіка та управління підприємствами (за видами економічної діяльності); ХНУМГ ім. О. М. Бекетова. - Харків: ХНУМГ імені О. М. Бекетова, 604 c.

10. Стейнер, Г. Стратегическое управление: принципь и межљународная практика [Текст] / Г. Стейнер, Дж. Майер; Пер. с англ. - М.: Международные отношения. -1998. - 352c.

11. Тридід, О.М. Організаційно-економічний механізм стратегічного розвитку підприємства. [Текст] / О.М. Тридід. - Х.: ХДЕУ, 2002. -364 c.

12. Шершньова, 3.С. Стратегічне управління [Текст] : підручник / 3.С. Шериньова. - К.: КНЕУ, 2004. - 699 c.

13. Glueck, W.F., Jauch, L.R. (1988) Business Policy and Strategic Management, 940.
14. Henderson, B. (1989) The origin of strategy, 139-143.

15. Robert S. Kaplan, David P. Norton (2004) Strategy Maps: Converting Intangible Assets into Tangible Outcomes, 324.

16. Методичні вказівки щуодо Кращчого Регулювання, [Електронний ресурс] / Європейська Комісія, Страсбург, 19.05.2015 РДП(2015) 111 (остаточна версія). Неофіційний переклад. Режим доступу: http://ec.europa.eu/smartregulation/guidelines/toc guide en.htm.

17. Анализ особенностей строительной отрасли Китая, инвестиционные проекты китайских строительных предприятий, их методы и механизмы. [Електронний ресурс]. Режим доcmyny https://studbooks.net/1793909/.

Рецензент: д-р екон. наук, проф. К. А. Мамонов, Харківський національний університет міського господарства імені О. М. Бекетова, Харків, Україна

Автор: ВЕЛИЧКО Володимир Анатолійович к.е.н., асистент кафедри Підприємництвва та бізнес адміністрування

Харківський національний університет міського господарства імені О. М. Бекетова

E-mail-hcsms.07@gmail.com

Автор: ГРИЦЬКОВ Євгеній Володимирович к.е.н., доцент кафедри Підприємництва та бізнес адміністрування

Харківський національний університет міського господарства імені О. М. Бекетова

E-mail-grickov777@gmail.com

\section{Автор: ЗУБАРЄВ Дмитро Васильович}

аспірант кафедри Підприємництва та бізнес адміністрування

Харківський національний університет міського господарства імені О. М. Бекетова

E-mail-kostia.mamonov2017@gmail.com

\section{НАПРЯМИ ФОРМУВАННЯ СТЕЙКХОЛДЕРНО-ОРІЕНТОВАНОЇ СТРАТЕГІЇ УПРАВЛІННЯ БУДІВЕЛЬНИМИ ПІДПРИЕМСТВАМИ: ВІТЧИЗНЯНИЙ І МІЖНАРОДНИЙ ДОСВІД}

В.А. Величко, С.В. Грицьков, Д.В. Зубарєв

Харківський національний університет міського господарства імені О.М. Бекетова, Україна

Доведено, щчо в сучасних умовах формування напрямів розвитку стейкхолдерно-орієнтованої стратегії управління будівельними підприємствами з урахуванням вітчизняного та міжнародного досвіду та впливу соиіальної корпоративної відповідальності набуває важливого значення. Метою дослідження є визначення напрямків розробки стейкхолдерно-орієнтованої стратегї управління будівельними підприємствами, з урахуванням вітчизняного та міжнародного досвіду та особливостей формування та реалізації сочіальної корпоративної відповідальності. Для досягнення мети дослідження вирішуються такі завдання: аналіз існуючих теоретичних положень щзодо формування та забезпечення взаємодії між зачікавленими сторонами будівельних компаній; виявлення основних аспектів відносин із зацікавленими сторонами у міжнародній практиці; формування напрямків розробки стейкхолдерно-орієнтованої стратегї управління будівельних підприємств з урахуванням впливу соціальної корпоративної відповідальності. В результаті дослідження запропоновані напрями розробки та реалізації стейкхолдерно-орієнтованої стратегії управління будівельних підприємств, щзо дозволило визначити методи та моделі, сформулювати методологічний підхід для інтегрованої оцінки рівня відносин із зацікавленими сторонами, та розробити заходи щчодо підвищення ефективності взаємодії із стейкхолдернами, спрямованої на підвищення інвестиційної привабливості будівельних підприємств. Сформовані локальні та інтегральну моделі, які враховують різні аспекти взаємодії стейкхолдерів із зачікавленими особами будівельних підприємств.

Пропонується застосовувати розроблену стратегію у вітчизняній та міжнародній практиці (китайські будівельні підприємства) з урахуванням сочіальної корпоративної відповідальності при забезпеченні взаємодї з різними групами зачікавлених сторін.

Ключові слова: стейкхолдерно-орієнтована стратегія, менеджмент, будівельні підприємства, функиіонування Китайського будівельного ринку, стейкхолдери, соиіальна корпоративна відповідальність. 